\title{
Expression of the cry1Ac in 'Arizona Common' Common Bermudagrass via Agrobacterium- mediated Transformation and Control of Black Cutworm
}

\author{
Hassan Salehi, Zahra Seddighi, Alexandra N. Kravchenko, and Mariam B. Sticklen ${ }^{1}$ \\ Department of Crop and Soil Sciences, Michigan State University, East Lansing, MI 48824
}

\begin{abstract}
AdDitional INDEX words. Agrotis ipsilon, Bacillus thuringiensis Berliner, Cynodon dactylon, gene transfer, insect resistance, tissue culture, turfgrass

Abstract. Bermudagrass (Cynodon L.C. Rich.) is grown on more than 4 million ha in the southern United States. The black cutworm (Agrotis ipsilon Hufnagel) is the most commonly encountered pest of bermudagrass, especially on golf course greens. Developing insect-resistant cultivars is a very desirable substitute, both environmentally and economically, to using current synthetic pesticides. Here we report, for the first time, Agrobacterium-mediated transformation of 'Arizona Common' common bermudagrass [Cynodon dactylon (L.) Pers.] with the Bacillus thuringiensis Berliner crylAc gene encoding an endotoxin active against black cutworm. Mature seeds were used for producing embryogenic callus, and calli were transformed with a plasmid containing a synthetic cry1Ac and the kanamycin resistance (nptII) genes. Putative transgenic calli and plantlets were selected on media containing 100 and $50 \mathrm{mg} \cdot \mathrm{L}^{-1} \mathrm{G} 418$, respectively. RNA-blot analysis of PCR-positive lines revealed the expression of the cry1Ac transgene in three out of five putative transgenic lines. The larvae fed on transgenic plant leaves experienced highly significant (over 80\%) mortality.
\end{abstract}

Common bermudagrass is a warm-season perennial species widely used for turf, forage, and soil stabilization (Anderson et al., 1998). The benefits of turf bermudagrass include a high level of wearability, salt and drought tolerance, and many pleasing aesthetic qualities (Gatschet, 1993). Bermudagrass is grown on more than 4 million ha in the southern United States (Burton, 1975) out of 12.2 million ha of turfgrass coverage nationwide (Potter, 1998).

In general, turf-infesting caterpillars (Noctuidae, Crambinae, and Pyralinae) are the major insect pests that feed on turf foliage (Shetlar, 2003). These insects cause severe discoloration, stunting, thinning and other aesthetic problems. The black cutworm is the most commonly encountered pest, especially on golf course greens, whether bentgrass (Agrostis L.) or bermudagrass (Shetlar, 2003). There is no report on the impact of black cutworm feeding on the yield of bermudagrass. However, it has been reported that fall armyworm (Spodoptera frugiperda J.E. Smith), another lepidopteran insect, caused 0.5 to $1.1 \mathrm{t}^{\mathrm{h}} \mathrm{ha}^{-1}$ yield loss of 'Coastal' common bermudagrass when artificially infested with population densities of 1.1 to 9.9 larvae per $0.1 \mathrm{~m}^{2}$ (Jamjanya and Quisenberry, 1988).

Traditionally, turfgrass improvement has relied on conventional breeding methods (Chai and Sticklen, 1998). Recent advanced molecular genetic techniques can accomplish the transfer of insect resistance within a much shorter time period, and transgenic insect-resistant cultivars are very desirable substitutes, both environmentally and economically, to using synthetic pesticides

\footnotetext{
Received for publication 29 Nov. 2004. Accepted for publication 13 Feb. 2005. The authors wish to thank Dr. I. Altosaar of the Univ. of Ottawa for providing the strain of Agrobacterium containing pKUC, Dr. C. Taliaferro of Oklahoma State Univ. for the Cynodon seeds, and the USDA-ARS Corn Insects and Crop Genetics Research Unit in Ames, Iowa, for the black cutworm larvae. The authors would like to thank the Government of Iran for the financial supports towards H. Salehi's fellowship for this research at Michigan State Univ.

${ }^{1}$ Corresponding author; e-mail: stickle1@msu.edu.
}

(Yamamoto and Engelke, 1998). There is only one report on gene transfer into common bermudagrass using Biolistic (Bio-Rad Lab, Hercules, Calif.) bombardment (Li and Qu, 2004) and two other reports on using Biolistic bombardment for genetic transformation of hybrid bermudagrass $(C$. dactylon $\mathrm{x} C$. transvaalensis Burtt-Davy) (Goldman et al., 2004; Zhang et al., 2003). In all of the above three reports, only marker genes have been transferred to the plants.

Common bermudagrass is a recalcitrant species in tissue culture and is highly recalcitrant with respect to the recovery of transgenic plants ( $\mathrm{Li}$ and $\mathrm{Qu}, 2004)$. To perform efficient genetic transformation of turfgrass species, it is necessary to identify the ideal explant type and optimize the in vitro conditions, mainly using different concentrations of various growth regulators for each genotype (Altpeter et al., 2000; Bai, 2001; Foster and Spangenberg, 1999). Monocotyledons such as grasses may not produce phenolic compounds like acetosyringone (Cheng et al., 2004). Using acetosyringone or other phenolic compounds in the culture medium might be useful for more efficient transformation.

Bacillus thuringiensis $(\mathrm{Bt})$ formulations have been used for more than 50 years as biological insecticides to control agricultural pests (Ahmad et al., 2002). The Bt insecticidal genes encode $\delta$ endotoxin crystal proteins, which are active against lepidopteran insects. These genes are widely accepted as important components of integrated pest management programs (Entwistle et al., 1993; Sticklen, 1991).

The objectives of the present study included development of systems for producing embryogenic calli and Agrobacterium-mediated transformation of common bermudagrass using $c r y l A c$, and testing the transgenic plants for resistance against black cutworm.

\section{Materials and Methods}

Plant materials. Mature hulled seeds of 'Arizona Common' common bermudagrass were used as explants. Seeds were 
prewashed in water with $0.2 \%$ Tween-20 for 15 min and rinsed three times with distilled water.

Tissue CUlTURE CONDITIONS. Tissue culture conditions followed Salehi and Khosh-Khui (2005) with minor alterations. The seeds were surface sterilized in $70 \%$ (v/v) ethanol for $1 \mathrm{~min}$, followed by $100 \%$ laundry bleach (5.25\% sodium hypochlorite) for $20 \mathrm{~min}$, and then rinsed six times with sterilized distilled water. Preliminary callus induction experiments were performed using Murashige and Skoog (1962) (MS) basal medium (Sigma-Aldrich, St. Louis) containing $30 \mathrm{~g} \cdot \mathrm{L}^{-1}$ maltose, $2.5 \mathrm{~g} \cdot \mathrm{L}^{-1}$ gelrite (Sigma-Aldrich), 4.5 to $40 \mu \mathrm{M}$ 2,4-dichlorophenoxyacetic acid (2,4-D) and 0 to 0.9 $\mu \mathrm{M} \mathrm{N}^{6}$-benzylamino purine (BAP). The medium containing the combination of $4.5 \mu \mathrm{M}$ 2,4-D and $0.45 \mu \mathrm{M}$ BAP was selected for callus induction. Four weeks later, the calli were cut to $3 \times 3-\mathrm{mm}$ pieces and subcultured every 4 weeks to the same fresh medium for 8 weeks more. Preliminary plant regeneration experiments were performed using MS medium containing $30 \mathrm{~g} \cdot \mathrm{L}^{-1}$ maltose and $2.5 \mathrm{~g} \cdot \mathrm{L}^{-1}$ gelrite, and different combinations of $\mathrm{BAP}(0$ to 7.5 $\mu \mathrm{M}), \propto$-naphthaleneacetic acid (NAA) (0 to $1 \mu \mathrm{M}), 2,4-\mathrm{D}$ (0 to 0.6 $\mu \mathrm{M})$ and gibberellic acid $\left(\mathrm{GA}_{3}\right)(0$ to $2 \mu \mathrm{M})$. The combination of $2 \mu \mathrm{M} \mathrm{GA}$ and $0.6 \mu \mathrm{M} 2,4-\mathrm{D}$ or only $0.6 \mu \mathrm{M}$ 2,4-D were selected for use in plant regeneration medium. The calli were kept in the same medium for 8 to 12 weeks, with one or two subcultures at 4-week intervals. Plantlets were transferred into the rooting medium, which included half-strength MS supplemented with $30 \mathrm{~g} \cdot \mathrm{L}^{-1}$ maltose and $2.5 \mathrm{~g} \cdot \mathrm{L}^{-1}$ gelrite. Media were autoclaved for $20 \mathrm{~min}$ at $121{ }^{\circ} \mathrm{C}$ and $147 \mathrm{kPa}$. All cultures were kept at 25 ${ }^{\circ} \mathrm{C}$. Cultures were kept in the dark for callus induction and were transferred to a $16 / 8 \mathrm{~h}$ light/dark photoperiod under $70 \mu \mathrm{mol} \cdot \mathrm{m}^{-2} \cdot \mathrm{s}^{-1}$ light intensity for plant regeneration and rooting.

Two-week-old well-rooted plantlets were transferred to $10-\mathrm{cm}$ pots containing Bacco potting medium (Michigan Peat Co., Houston), acclimatized, and transferred to the greenhouse. Greenhouse conditions were 25 to $28{ }^{\circ} \mathrm{C}, 90 \%$ to $95 \%$ relative humidity and continuous $190 \mu \mathrm{mol} \cdot \mathrm{m}^{-2} \cdot \mathrm{s}^{-1}$ light intensity.

Plasmid construct. Transformation experiments were conducted using A. tumefaciens E. F. Sm. \& Towns., Conn. strain LBA 4404 (Hoekema et al., 1983) containing the binary vector KUC (Fig. 1). Plasmid KUC (Cheng et al., 1998) contains a synthetic crylAc from $B$. thuringiensis, under the control of ubiquitin promoter and nopaline synthase $(\mathrm{N})$ terminator. This plasmid also contains a hygromycin-B resistance gene ( $h p t)$, and a $\beta$-glucuronidase gene ( $g$ us), each under the control of cauliflower mosaic virus 35S (CaMV 35S) promoter and $\mathrm{N}$ terminator, and a kanamycin resistance gene (nptII) under the control of N promoter and terminator (Fig. 1).

Preparation of bacterial suspension. A single colony of A. tumefaciens containing pKUC was grown in $10 \mathrm{~mL}$ YEP medium [containing $10 \mathrm{~g} \cdot \mathrm{L}^{-1}$ Bacto peptone (Difco, Detroit), 10 $\mathrm{g} \cdot \mathrm{L}^{-1}$ Bacto yeast extract (Difco), $5 \mathrm{~g} \cdot \mathrm{L}^{-1} \mathrm{NaCl}, \mathrm{pH}$ 7.2) supple-

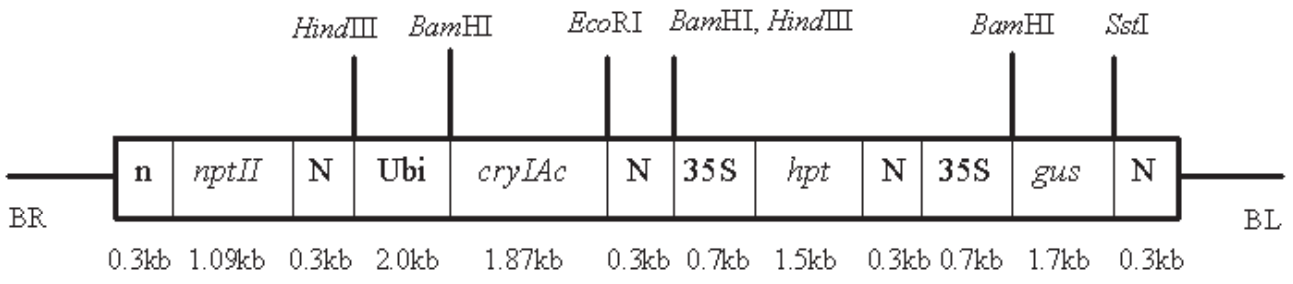

Fig. 1. Restriction map of the T-DNA of pKUC. BR, T-DNA right border; BL, T-DNA left border; crylAc synthetic insecticidal gene from B. thuringiensis; $h p t$, hygromycin phosphotransferase gene; gus = $\beta$-glucuronidase gene; $n p t I I=$ neomycin phosphotransferase gene; $35 \mathrm{~S}=\mathrm{CaMV} 35 \mathrm{~S}$ promoter; Ubi = maize ubiquitin promoter; $\mathrm{N}=$ nopaline synthase terminator; $\mathrm{n}=$ nopaline synthase promoter. mented with $50 \mathrm{mg} \cdot \mathrm{L}^{-1}$ of both hygromycin-B and kanamycin (Ahmad et al., 2002), incubated at $28^{\circ} \mathrm{C}$ and $250 \mathrm{rpm}$ for $72 \mathrm{~h}$. The cultures with optical density $(\mathrm{OD})$ of $\approx 1.0$ at $\mathrm{A}_{600}$ were used for transformation.

SENSITIVITY OF CYNODON CALLI AND STEM PIECES TO G418. The untransformed callus and stem pieces were tested in MS basal medium containing $0,25,50,75,100,125$, and $150 \mathrm{mg} \cdot \mathrm{L}^{-1}$ of G418 (Stratagene Co., La Jolla, Calif.) for 2 weeks. The selected concentrations (100 and $50 \mathrm{mg} \cdot \mathrm{L}^{-1}$ ) were used for further transgenic callus and plantlet selection, respectively.

TOBACCO LEAF EXTRACT PREPARATION. Eight grams of tobacco (Nicotiana tabacum L. 'Samsun') leaves were ground using liquid nitrogen, and the powder was dissolved in distilled water in a 15 $\mathrm{mL}$ polypropylene tube (Corning, Corning, N.Y.) up to $10 \mathrm{~mL}$. After centrifugation of the solution at $850 \mathrm{~g}_{\mathrm{n}}$ for $20 \mathrm{~min}$, the supernatant was carefully passed through Whatman \#1 filter paper (Sigma-Aldrich) and transferred to a new tube. Then, distilled water was added to the solution to make $10 \mathrm{~mL}$ volume. This stock was maintained at $-20^{\circ} \mathrm{C}$ until used.

AGROBACTERIUM-MEDIATED TRANSFORMATION. Four-week-old embryogenic calli, $3 \times 3-\mathrm{mm}$ pieces, were infected by immersing in the Agrobacterium culture under $400 \mathrm{~mm} \mathrm{Hg}$ pressure for 30 min. After inoculation, the calli were blotted on sterilized filter papers, and cultured on co-cultivation medium (callus induction medium supplemented with $100 \mu \mathrm{M}$ acetosyringone (SigmaAldrich), $0.2 \%(\mathrm{v} / \mathrm{v})$ tobacco leaf extract, or a combination of both). After three days of co-cultivation in the dark, the calli were rinsed three times in washing medium containing liquid MS basal medium and $400 \mathrm{mg} \cdot \mathrm{L}^{-1}$ cefotaxime (Sigma-Aldrich) to prevent Agrobacterium overgrowth. Samples were gently hand-agitates for a few minutes at each rinsing time to help exposure of explants to cefotaxime and the removal of the Agrobacterium. Samples were then blotted onto sterilized filter papers and cultured on callus induction medium supplemented with $250 \mathrm{mg} \cdot \mathrm{L}^{-1}$ cefotaxime, and $100 \mathrm{mg} \cdot \mathrm{L}^{-1} \mathrm{G} 418$ for selection of the putative transformants. The washing was performed every 4 weeks for a total of 12 to 16 weeks. G418-resistant calli were then transferred to plant regeneration medium, supplemented with $250 \mathrm{mg} \cdot \mathrm{L}^{-1}$ cefotaxime and $50 \mathrm{mg} \cdot \mathrm{L}^{-1} \mathrm{G} 418$ under light conditions.

Plantlets were transferred to rooting medium supplemented with $250 \mathrm{mg} \cdot \mathrm{L}^{-1}$ cefotaxime and $50 \mathrm{mg} \cdot \mathrm{L}^{-1} \mathrm{G} 418$. In all of the above media, acetosyringone, tobacco leaf extract, cefotaxime and G418 were filter-sterilized and added in the appropriate media after autoclaving and cooling to $50{ }^{\circ} \mathrm{C}$. Two weeks later, the well-rooted plantlets were transferred to pots, acclimated and then transferred to the greenhouse.

GUS ASSAY. Histochemical assay for GUS activity in putative transgenic calli was done as described by Jefferson et al. (1987). The callus pieces were placed in 5-bromo-4-chloro-3-indolylbeta-D-glucuronic acid (X-gluc) (Amersham Biosciences, Piscataway, N.J.) solution, incubated at $37{ }^{\circ} \mathrm{C}$ overnight, then the color changes observed under a dissecting microscope.

Polymerase chain reaction (PCR) ANALYSIS. PCR analysis of plants was used to screen the putatively transgenic plants for cry $1 A c$ transgene incorporation. Total genomic DNA of control and transgenic plants was extracted from shoots as 
described by Edwards et al. (1991). The following set of primers was used: $c r y 1 A c$ F, 5'-ACA GAA GAC CCT TCA ATA TC-3' (forward primer) and $c r y l A c$ R, 5'-GTT ACC GAG TGA AGA TGT AA-3' (reverse primer). The predicted size of the amplified DNA fragments was $606 \mathrm{bp}$. DNA amplifications were performed in a thermocycler (Perkin Elmer/Applied Biosystem, Foster City, Calif.) using REDTaq ReadyMix PCR Reaction Mix with $\mathrm{MgCl}_{2}$ (Sigma-Aldrich). The PCR profile had an initial denaturation step at $94^{\circ} \mathrm{C}$ for $1 \mathrm{~min}$, followed by 30 cycles of $1 \mathrm{~min}$ at $94^{\circ} \mathrm{C}$ (denaturation), $2 \mathrm{~min}$ at $60{ }^{\circ} \mathrm{C}$ (annealing), and $3 \mathrm{~min}$ at $72{ }^{\circ} \mathrm{C}$ (extension). The reaction mixture was loaded directly onto a $1.0 \%$ $(\mathrm{w} / \mathrm{v})$ agarose gel, stained with ethidium bromide and visualized with ultraviolet light.

RNA-BLOT ANALYSIS. Total RNA of control and five putative transgenic lines was isolated from shoots using the TRI Reagent (Sigma-Aldrich) according to the manufacturer's instructions. Aliquots of RNA $(20 \mu \mathrm{g})$ were fractionated in a $1.2 \%$ agarose formaldehyde denaturing gel and blotted to a Hybond- $\mathrm{N}^{+}$nylon membrane (Amersham Pharmatica Biotech., Piscataway, N.J.) as specified by the manufacturer. The probe was generated by digesting plasmid DNA with BamHI and EcoRI, and releasing the $1.87-\mathrm{kb}$ fragment containing the $c r y l A c$-coding region. The restriction fragment was gel-purified using the QIAquick Gel Extraction Kit (QIAGEN, Valencia, Calif.). The probe labeling and transcript detection were obtained using the DIG-High Prime DNA Labeling and Detection Starter Kit II (kit for chemiluminescent detection with CSPD; Roche Diagnostics Co., Indianapolis) following the manufacturer's protocol.

InSECT BIOASSAYS. Insect toxicity of the transgenic Cynodon plants expressing $c r y 1 A c$ (lines 1,4 , and 5) was tested by feeding assays with black cutworm larvae. Five leaf pieces (60 mg in total) were cut from greenhouse-grown control and transgenic plants and placed on moist filter papers in petri dishes $(60 \times 15$ $\mathrm{mm}$ ). Five first neonate larvae, each $\approx 100 \mu \mathrm{g}$, were placed on leaf segments with a soft camel-hair brush, and allowed to fed on the leaf pieces for $5 \mathrm{~d}$. The experiment was repeated twice. Each experiment included four replications. Data on insect mortality, increase in larvae mass and decrease in leaf fresh mass were recorded $5 \mathrm{~d}$ after starting the feeding assay. Analysis of variance was conducted using PROC GLM (SAS institute, 2002). The percentage data were transformed to arcsine before analysis. The means were compared using $t$ test when ANOVA results were statistically significant $(P \leq 0.01)$.

\section{Results and Discussion}

Tissue Culture STUdies. Using $40 \mu \mathrm{M}$ 2,4-D alone in callus induction medium we were not able to produce any embryogenic callus in 'Arizona Common' common bermudagrass. Salehi and Khosh-Khui (2005) used the same amount of 2,4-D and produced $100 \%$ embryogenic callus in common bermudagrass (Califorina origin). $\mathrm{Li}$ and $\mathrm{Qu}$ (2004) included 0.9 $\mu \mathrm{M}$ BAP along with 4.5 $\mu \mathrm{M} 2,4-\mathrm{D}$ in their callus induction medium for ' $\mathrm{J} 1224$ ' common bermudagrass. Our results show that production of embryogenic callus of 'Arizona Common' requires a combination of both 2,4$\mathrm{D}$ and BAP with concentrations of 4.5 and $0.45 \mu \mathrm{M}$, respectively (Fig. 2A).

Our observations with plantlet regeneration of common bermudagrass showed that 'Arizona Common' is a recalcitrant cultivar in tissue culture and confirmed the results of $\mathrm{Li}$ and Qu (2004) who worked on other cultivars of common bermudagrass. None of the combinations of BAP, NAA, and $\mathrm{GA}_{3}$ resulted in plantlet regeneration. However, a combination of $2 \mu \mathrm{M} \mathrm{GA}$ and $0.6 \mu \mathrm{M}$ 2,4-D or only $0.6 \mu \mathrm{M} 2,4-\mathrm{D}$ resulted in shootlet regeneration and elongation. Therefore, we conclude that regeneration of common bermudagarass is highly genotype specific.

GUS EXPRESSION. Histochemical analysis showed GUS expression in transformed calli, after three days co-cultivation (Fig. 2C). None of the control calli showed GUS expression.

AGROBACTERIUM-MEDIATED TRANSFORMATION. Our experiment showed that using a combination of both acetosyringone and tobacco leaf extract could result in $100 \%$ transient GUS expression as compared to $\approx 60 \%$ when acetosyringone or tobacco leaf extract were used alone (data not shown). The same amount of acetosyringone was used by Luo et al. (2004) for Agrostis stolonifera L., by Chai et al. (2004) for Agrostis tenuis Sibth., and by Bettany et al. (2003) for Festuca arundinacea Schreb. and Lolium multiflorum Lam. Luo et al. (2004) observed transient GUS expression in $\approx 60 \%$ of calli tested, the same as our experiment when using either acetosyringone or tobacco leaf extract. Acetosyringone is a phenolic compound that can induce vir genes that are responsible for the transfer of T-DNA from A. tumefaciens to the wounded
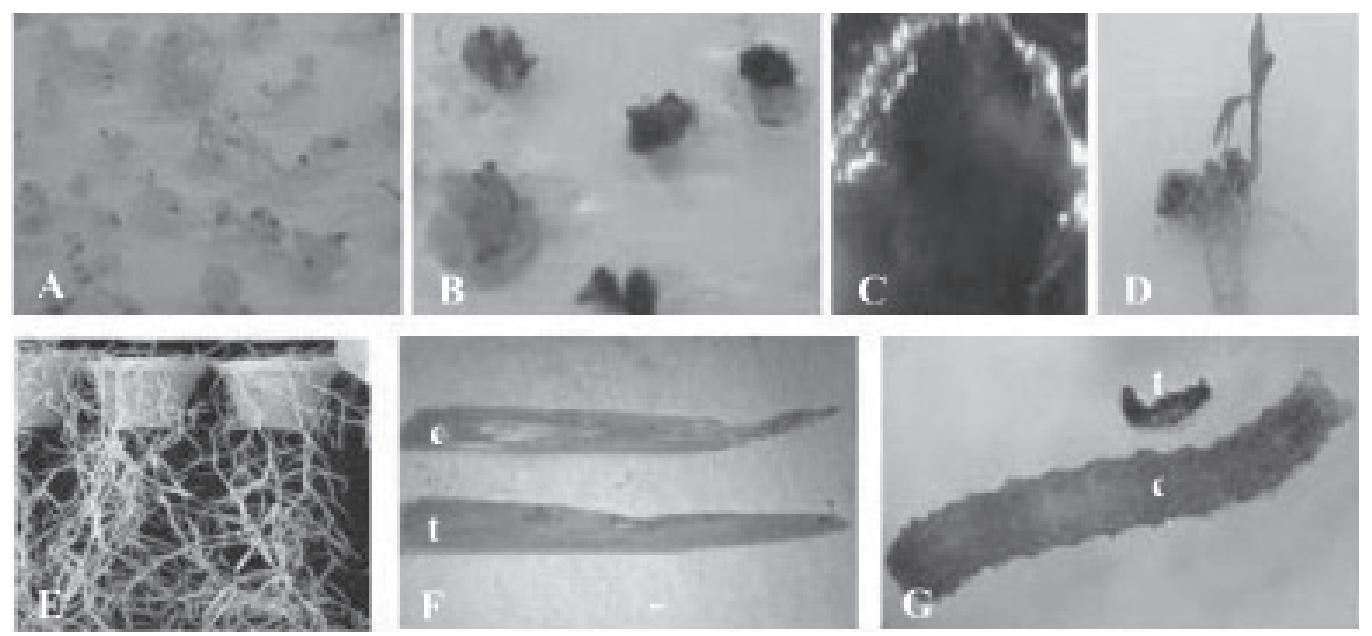

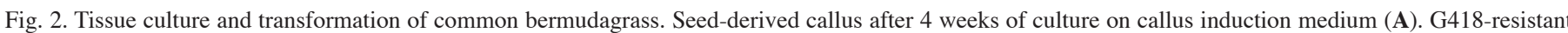

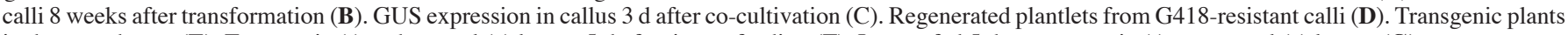
in the greenhouse $(\mathbf{E})$. Transgenic (t) and control (c) leaves $5 \mathrm{~d}$ after insect feeding $(\mathbf{F})$. Insects fed $5 \mathrm{~d}$ on transgenic (t) vs. control (c) leaves $(\mathbf{G})$. 
host cell (Cheng et al., 2004; Toyama et al., 2002; Stachel et al., 1985). Monocotyledons, particularly the grasses, may not produce phenolic compounds like acetosyringone, or if they do, not at a level sufficient to serve as signal molecules (Cheng et al., 2004). Tobacco contains phenolic compounds including acetosyringone and $\alpha$-hydroxy acetosyringone. More studies are needed to see which of the tobacco phenolic compounds may have contributed toward the improved transformation efficiency.

The G418-resistant calli (Fig. 2B) regenerated into somatic embryos which were rooted (Fig. 2D) and grown in the greenhouse (Fig. 2E). All the transgenic plants resembled untransformed plants in morphology. A transformation efficiency of 5\% was obtained (data not shown).

Polymerase chain reaction. As shown in Fig. 3, in addition to the band seen with the positive control, a band of the expected size of 606 bp was amplified from the genomic DNA from five regenerated plantlets, originating from separate calli. No band was detected in the untransformed control.

EXPRESSION OF CRY1Ac. RNA-blot analysis of PCR-positive transformed plants showed the presence of crylAc mRNA transcripts in shoot tissues of three lines $(1,4$, and 5) at detectable levels (Fig. 4). There was no detectable transcript for the untransformed control plant. Therefore, based on RNA-blot analysis, three out of five (60\%) PCR-positive lines showed crylAc expression.

INSECT FEEDING ASSAYS. We chose the black cutworm because it has been reported to be the most commonly encountered pest of bermudagrass (Shetlar, 2003). Larvae mortality of $80 \%$ to $100 \%$ with the mean of $82.5 \%$ was observed in transgenic plants, whereas the control showed $20 \%$ to $40 \%$ with the mean of $30 \%$ (Table 1 ). The insect mortality in the control plants is related to the damages made to the tiny first star larvae during their transfer using a camel brush. It is assumed that some of the mortality of insects feeding on transgenic plants might be due to the same reason.

There is no report of expression of the crylAc gene in any of the turfgrasses. In transgenic rice, varying degrees of mortality $(0 \%$ to $100 \%)$ have been reported against rice yellow stem borer (Scirpophaga insertulas Wlk.), striped stem borer (Chilo supressalis Walker), rice leaf folder (Cnaphalocrocis medinalis Guenee), and european corn borer (Ostrinia nubilalis Hubner) feeding on $c r y l A b$ and $c r y l A c$ transgenic plants (Ahmad et al., 2002; Cheng et al., 1998; Fujimoto et al., 1993; Maqbool et al., 2001; Nayak et al., 1997).

Significant leaf damage was seen in control plants as a result of black cutworm feeding, whereas in transgenic leaves, there was little detectable damage (Fig. 2F). Decrease in leaf fresh mass in the control was more than twice that of the transgenic plants (Table 1).

There was a significant increase in fresh weight of the larvae that were fed on untransformed control leaves compared to those fed on transgenic leaves (Table 1, Fig. 2G). The feeding assay confirmed the accuracy of RNA-blot analysis results in common bermudagrass plants. The transgenic crylAc common bermudagrass should be a very desirable alternative to synthetic pesticides, for both environmental and economical concerns.

In this study, we report an Agrobacterium-mediated transformation system using an agronomically important gene in common bermudagrass. Agrobacterium-mediated transformation of higher plants has been favored due to the generally low copy number of the integrated transgene and the fact that transgenes are usually transmitted to progeny in an expected Mendelian fashion (Luo et al., 2004). The Agrobacterium-mediated transformation system might be useful for other cultivars of common bermudagrass or

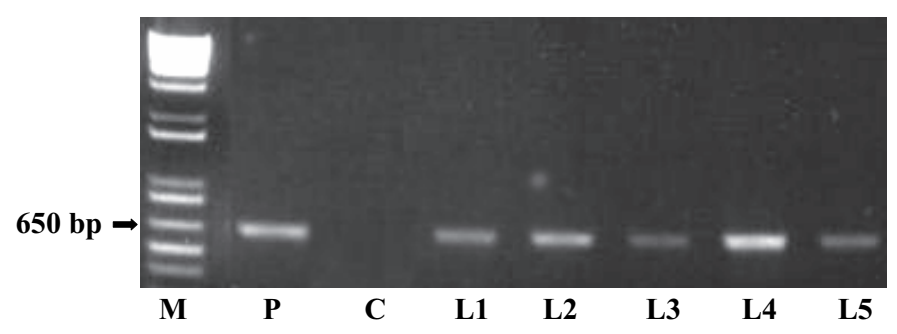

Fig. 3. Polymerase chain reaction (PCR) analysis of putatively transgenic common bermudagrass plants showing $606 \mathrm{bp}$ fragment corresponding to $\mathrm{cry} 1 \mathrm{Ac}$. Lanes: $\mathrm{M}=1 \mathrm{~kb}$ Plus marker; $\mathrm{P}=$ plasmid (KUC) as positive control; $\mathrm{C}=$ untransformed control; L1 to L5 = putative transgenic lines.

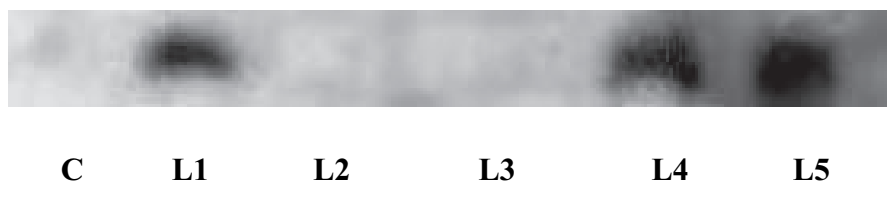

Fig. 4. The RNA-blot showing expression of crylAc in putative transgenic common bermudagrass plants. Lanes: $\mathrm{C}=$ untransformed control; L1 to L5 = putative transgenic lines.

Table 1. Insecticidal activity and performance of transgenic common bermudagrass plants to black cutworm after $5 \mathrm{~d}$ feeding.

\begin{tabular}{lccc}
\hline & $\begin{array}{c}\text { Larvae } \\
\text { mortality } \\
(\% \pm \mathrm{SD})\end{array}$ & $\begin{array}{c}\text { Increase in each } \\
\text { larvae mass } \\
\text { Plant }\end{array}$ & $\begin{array}{c}\text { Decrease in } \\
\text { leaf mass } \\
(\mu \mathrm{g} \pm \mathrm{SD})\end{array}$ \\
\hline Control & $30.0 \pm 15.12^{\mathrm{y}}$ & $267.5 \pm 118.80$ & $4.0 \pm 0.35$ \\
Transformed & $82.5 \pm 19.82$ & $56.2 \pm 102.50$ & $1.9 \pm 0.32$
\end{tabular}

${ }^{\mathrm{z}}$ Decrease in total mass (five leaf pieces).

yMeans of control and transformed plant in each column are significantly different $(P \leq 0.01)$ using $t$ test.

hybrid bermudagrass. However, we recommend investigating efficient in vitro regeneration for each cultivar before transformation.

\section{Literature Cited}

Ahmad, A., S.B. Maqbool, S. Riazuddin, and M.B. Sticklen. 2002. Expression of synthetic crylAb and crylAc genes in Basmati rice (Oryza sativa L.) variety 370 via Agrobacterium-mediated transformation for the control of the european corn borer (Ostrinia nubilalis). In Vitro Cell. Dev. Biol.-Plant 38:213-220.

Altpeter, F., J. Xu, and S. Ahmed. 2000. Generation of large numbers of independently transformed fertile perennial ryegrass (Lolium perenne $\mathrm{L}$.) plants of forage- and turf-type cultivars. Mol. Breeding 6:519-528.

Anderson, M.P., C. Taliaferro, M. Gatschet, B. de los Reyes, and S. Assefa. 1998. Molecular identification of cold acclimation genes in, and phylogenetic relationships among Cynodon species, p. 115-134. In: M.B. Sticklen and M.P. Kenna (eds.). Turfgrass biotechnology, cell and molecular genetic approaches to turfgrass improvement. Ann Arbor Press, Chelsea, Mich.

Bai, Y. 2001. Tissue culture and genetic transformation of tall fescue. PhD Diss., North Carolina State Univ., Raleigh.

Bettany, A.J.E., S.J. Dalton, E. Timms, B. Manderyck, M.S. Dhanoa, and P. Morris. 2003. Agrobacterium tumefaciens-mediated transformation of Festuca arundinacea (Schreb.) and Lolium multiflorum (Lam.). Plant Cell Rpt. 21:437-444.

Burton, G.W. 1975. Breeding better forages to help feed man and preserve and enhance the environment. Bioscience 23:705-710.

Chai, B. and M.B. Sticklen. 1998. Application of biotechnology in turfgrass genetic improvement. Crop Sci. 38:1320-1338.

Chai, M.L., K.K. Senthil, and D.H. Kim. 2004. Transgenic plants of colonial bentgrass from embryogenic callus via Agrobacterium-mediated 
transformation. Plant Cell Tiss. Org. Cult. 77:165-171.

Cheng, M., B.A. Lowe, T.M. Spencer, X. Ye, and C.L. Armstrong. 2004. Factors influencing Agrobacterium-mediated transformation of monocotyledonous species. In Vitro Cell. Dev. Biol.-Plant 40:31-45.

Cheng, X., R. Sardana, H. Kaplan, and I. Altosaar. 1998. Agrobacteriumtransformed rice plants expressing synthetic $\operatorname{cry} 1 A(b)$ and $\operatorname{cry} l A(c)$ genes are highly toxic to striped stem borer and yellow stem borer. Proc. Natl. Acad. Sci. USA 95:2767-2772.

Edwards, K., C. Johnstone, and C. Thompson. 1991. A simple and rapid method for the preparation of plant genomic DNA for PCR analysis. Nucleic Acids Res. 19:1349.

Entwistle, P.F., M.J. Bailey, J. Cory, and S. Higgs. 1993. Bacillus thuringiensis: An environmental biopesticide: Theory and practice. Wiley, New York.

Foster, J.W. and G.C. Spangenberg. 1999. Forage and turf-grass biotechnology: Principles, methods and prospects, p. 191-237. In: J.K. Setlow (ed.). Genetic engineering, Vol. 21. Kluwer Acad./Plenum, New York.

Fujimoto, H., K. Itoh, M. Yamamoto, J. Kyozuka, and K. Shimamoto. 1993. Insect resistant rice generated by introduction of a modified delta-endotoxin gene of Bacillus thuringiensis. Bio/Technology 11:1151-1155.

Gatschet, M. 1993. Alterations in protein synthesis associated with cold acclimation in bermudagrass (Cynodon spp.). PhD Diss., Oklahoma State Univ., Stillwater.

Goldman, J.J., W.W. Hanna, G.H. Fleming, and P. Ozias-Akins. 2004. Ploidy variation among herbicide-resistant bermudagrass plants of cv. TifEagle transformed with the bar gene. Plant Cell Rpt. 22:553-560.

Hoekema, A., P.R. Hirsch, P.J.J. Hooykaas, and R.A. Schilperoort. 1983. A binary plant vector strategy based on separation of vir-and T-region of the Agrobacterium tumefaciens Ti-plasmid. Nature 303:179-180.

Jamjanya, T. and S.S. Quisenberry. 1988. Impact of fall armyworm lepidoptera noctuidae feeding on the quality and yield of Coastal bermudagrass. J. Econ. Entom. 81:922-926.

Jefferson, R.A., T.A. Kavanagh, and M.W. Bevan. 1987. GUS fusions: $\beta$-glucuronidase as a sensitive and versatile gene fusion marker in higher plants. EMBO J. 6:3901-3907.

Li, L. and R. Qu. 2004. Development of highly regenerable callus lines and Biolistic transformation of turf-type common bermudagrass [ $\mathrm{Cyn}$ odon dactylon (L.), Pers.]. Plant Cell Rep. 22:403-407.

Luo, H., Q. Hu, K. Nelson, C. Longo, A.P. Kausch, J.M. Chandlee, J.K. Wipff, and C.R. Fricker. 2004. Agrobacterium tumefaciens-mediated creeping bentgrass (Agrostis stolonifera L.) transformation using phosphinothricin selection results in a high frequency of single-copy transgene integration. Plant Cell Rpt. 22:645-652.

Maqbool, S.B., S. Riazuddin, N.T. Loc, A.R.M. Gatehouse, J.A. Gatehouse, and P. Christou. 2001. Expression of multiple insecticidal genes confers broad resistance against a range of different rice pests. Mol. Breed. 7:85-93.

Murashige, T. and F. Skoog. 1962. Arevised medium for rapid growth and bioassay with tobacco tissue cultures. Physiol. Plant. I5:473-497.

Nayak, P., D. Basu, S. Das, A. Basu, D. Ghosh, N.A. Ramakrishnan, M. Ghosh, and S.K. Sau. 1997. Transgenic elite indica rice plants expressing Cry1Ac-endotoxin of Bacillus thuringiensis are resistant against yellow stem borer (Scirpophaga incertulas). Proc. Natl. Acad. Sci. USA 94:2111-2116.

Potter, D.A. 1998. Destructive turfgrass insects, biology, diagnosis and control. Ann Arbor Press, Chelsea, Mich.

Salehi, H. and M. Khosh-Khui. 2005. Effects of genotypes and plant growth regulators on callus induction and plant regeneration in four important turfgrass genera (a comparative study). In Vitro Cell. Dev. Biol.-Plant (In Press).

SAS Institute. 2002. SAS user's guide: Statistics. SAS Inst., Cary, N.C.

Shetlar, D.J. 2003. General turf insects-identification, biology \& principles of control. The Ohio State Univ., Columbus, Ohio.

Stachel, S.E., E. Messens, M. Van Montagu, and P. Zambryski. 1985. Identification of the signal molecules produced by wounded plant cells that activate T-DNA transfer in Agrobacterium tumefaciens. Nature 318:624-629.

Sticklen, M.B. 1991. Genetic engineering of plants: an alternative to pesticides and a new component of integrated pest management, $p$. 522-566. In: D.L. Weigmann (ed.). Pesticides for the next decades: The challenges ahead, VPI Pub., Blacksburg, Va.

Toyama, K., C.H. Bae, M.S. Seo, I.J. Song, Y.P. Lim, P.S. Song, and H.Y. Lee. 2002. Overcoming of barriers to transformation in monocot plants. J. Plant Biotechnol. 4:135-141.

Yamamoto, I. and M.C. Engelke. 1998. Utilizing in vitro culture for the direct improvement of turfgrass cultivars, p. 165-172. In: M.B. Sticklen and M.P. Kenna (eds.). Turfgrass biotechnology, cell and molecular genetic approaches to turfgrass improvement. Ann Arbor Press, Chelsea, Mich.

Zhang, G., S. Lu, T.A. Chen, C.R. Funk, and W.A. Meyer. 2003. Transformation of triploid bermudagrass (Cynodon dactylon $\times C$. transvaalensis cv. TifEagle) by means of biolistic bombardment. Plant Cell Rpt. 21:860-864. 